\title{
REUTILIZACIÓN DE IMÁGENES DE ARCHIVO EN TELEVISIÓN: DERECHOS DE PROPIEDAD Y DE USO
}

\section{Paloma Hidalgo-Goyanes e Iris López-De-Solís}
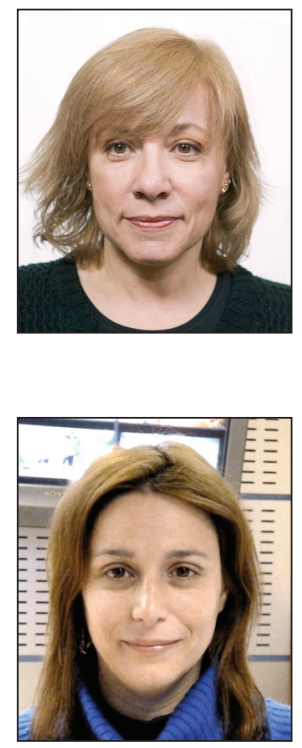

Paloma Hidalgo-Goyanes es licenciada con grado en geografía e historia, diplomada en archivos y documentación, especialista universitaria en documentación y DEA en CC. de la información. Jefa de la Unidad de Análisis Documental PPII de TVE y profesora asociada de documentación en la Facultad de CC. de la Información de la Universidad Complutense de Madrid. Docente del Master de documentación audiovisual (Universidad Carlos III de Madrid - IRTVE) y en otros masters de documentación informativa y audiovisual. Autora de diversas publicaciones sobre documentación audiovisual en televisión y gestión del patrimonio audiovisual.

http://orcid.org/0000-0001-8290-5206

paloma.hidalgo@rtve.es

Iris López-De-Solís es licenciada en historia por la Universidad Complutense de Madrid (UCM), máster en información y documentación por la Universidad Carlos III de Madrid (UC3M) y DEA en documentación por la UCM donde actualmente lleva a cabo su tesis doctoral. Trabaja como documentalista en los Servicios Informativos de TVE en Madrid. Es docente en el Master de documentación audiovisual del Instituto de Radio Televisión Española (IRTVE) y la UC3M. Sus líneas de investigación se centran en documentación audiovisual en cine y televisión. Es autora del libro El film researcher (Editorial UOC, 2013).

http://orcid.org/0000-0003-0957-7474

iris.lopez@rtve.es

Televisión Española (TVE). Torrespaña Alcalde Sáinz de Baranda, 92. 28007 Madrid, España

\section{Resumen}

La reutilización de imágenes de archivo es habitual en la producción de televisión, para completar o contextualizar una noticia, elaborar biografías, necrológicas, efemérides, como recurso cuando no existen imágenes de alguna noticia o para completar las parrillas de emisión. No todas las imágenes que se conservan en los archivos de las televisiones pueden reutilizarse: los derechos contractuales, la propiedad intelectual y los derechos fundamentales de las personas deben salvaguardarse; el desconocimiento o incumplimiento de estas pautas y de las restricciones de reutilización de algunos documentos genera problemas. La utilización de imágenes procedentes de Internet se ha convertido en una práctica habitual sin embargo, debido a sus especiales características, estas imágenes deben ser empleadas con sumo cuidado.

\section{Palabras clave}

Documentación audiovisual, Archivos audiovisuales, Imágenes de archivo, Películas, Videos, Servicios informativos, Derecho audiovisual, Reutilización, Derechos de propiedad, Derechos de uso, Derechos de autor, Copyright, Leyes, Legislación, Preservación de la intimidad, Emisoras de televisión, Canales de TV, Cadenas de TV.

Title: Reuse of television archives footage: property and use rights

\section{Abstract}

The reuse of archive footage is usual in television productions to complete or contextualize a story, to develop a biography or to cover anniversaries. Other times it is used when there are no current images related to the story or just to fill the schedule grid. However, not all archive materials can be reused; contractual rights, intellectual property and individuals' fundamental rights must be preserved. The lack of awareness of these standards and restrictions can create problems. Pictures from the Internet have become another common audiovisual source, but due to their special characteristics, they must be used very carefully.

\section{Keywords}

Audiovisual documentation, Audiovisual archives, Archive footage, Pictures, Video, News services, Audiovisual rights, Copyright, Laws, Legislation, Use rights, Privacy, Television stations, TV channels. 
Hidalgo-Goyanes, Paloma; López-De-Solís, Iris (2014). "Reutilización de imágenes de archivo en televisión: derechos de propiedad y de uso". El profesional de la información, enero-febrero, v. 23, n. 1, pp. 65-71.

http://dx.doi.org/10.3145/epi.2014.ene.08

\section{Introducción}

La consulta y utilización de documentación para la elaboración de la información en los medios de comunicación redunda en el aumento de la calidad del mensaje informativo. El buen empleo de documentación es un valor añadido que se refleja sin lugar a dudas en el resultado final del trabajo realizado, aunque en estos momentos la proliferación de medios de comunicación digitales y la importancia que ha cobrado la rapidez (la inmediatez) en difundir la información haya dejado en segundo plano en ocasiones el rigor y la calidad de la información. La existencia de un buen archivo audiovisual en una empresa de televisión es uno de sus activos más importantes dada la rentabilidad económica y profesional que proporcionan.

La Federación Internacional de Archivos de Televisión (FIAT) en sus directrices para el uso correcto del material de archivo en las cadenas de televisión tenía en cuenta que estas orientaciones no podían asegurar el proceder correcto al respecto del material de archivo, tal y como se hacía constar en la introducción: "Estas directrices tienen como objetivo ser útiles tanto para los archiveros como para los usuarios del material de archivo (productores, realizadores de programas). Ambas partes comparten responsabilidades en el buen uso del archivo. El personal del archivo debe facilitar información y puede expresar su opinión, pero la decisión y la responsabilidad del uso final del material de archivo pertenece a los productores"1.

La correcta reutilización de imágenes de archivo debe salvaguardar el derecho al honor, a la intimidad personal y familiar y a la propia imagen, así como los derechos de autor y contractuales

En este contexto hay que analizar la reutilización de imágenes de archivo, una práctica habitual en la producción diaria de las televisiones (Agirreazaldegi-Berriozabal, 1997), especialmente en el área de informativos: Se usan para completar, contextualizar o narrar los antecedentes de una noticia, para elaborar biografías y/o necrológicas, en efemérides, o como recurso cuando no existen imágenes actuales o relacionadas con alguna información.

Por nuestra experiencia como documentalistas de televisión, sabemos que en la actualidad más de un $40 \%$ de la información diaria de los programas informativos incluye imágenes de archivo, bien sea completando las imágenes captadas de cada información o como recurso visual cuando no existen imágenes de las mismas. La proporción varía según las áreas de especialización informativa: la reutilización de imágenes de archivo suele ser mayor en las informacio- nes del área de sociedad o economía y menor en las noticias de deportes o política nacional (informaciones en las que la reutilización de imágenes metonímicas -relacionadas con el tema- o de simple recurso es menos necesaria debido a la cantidad de imágenes que se generan diariamente al respecto). Las cifras de reutilización son también distintas dependiendo de los momentos y tempos informativos: aumenta considerablemente en los períodos vacacionales (verano, navidades, etc.) puesto que habitualmente en estas épocas se genera menos información relevante y hay que "rellenar" los informativos con otro tipo de crónicas; a finales de año, la elaboración de los consabidos resúmenes anuales conlleva también el aumento del uso del material de archivo. Sin embargo, la demanda disminuye en momentos de sobreabundancia informativa (celebración de eventos deportivos importantes: Campeonato Mundial de Natación Barcelona, 2013; catástrofes naturales: terremoto "Yolanda" en Filipinas, en noviembre de 2013; o si se producen sucesos puntuales, como el accidente ferroviario en las proximidades de Santiago de Compostela en julio de este mismo año 2013, o el naufragio de inmigrantes cerca de la isla italiana de Lampedusa en octubre de 2013) ocasiones en las que lógicamente abundan las imágenes que se captan en directo y por tanto la necesidad de reutilizar imágenes de archivo para elaborar la información diaria es menor.

Desde hace algunos años, la aparición de múltiples canales y los problemas económicos obligan a las televisiones a rentabilizar aún en mayor medida sus recursos, entre ellos el archivo audiovisual, para ahorrar dinero y tiempo en la producción y en la emisión diarias (son muchas las horas que deben rellenarse en las parrillas de emisión de los diferentes canales de televisión).

En líneas generales y resumiendo en lo posible, podríamos decir que en los archivos de televisión se gestionan y conservan dos clases de documentos audiovisuales bien diferenciados en atención al origen de su producción:

- Producción propia, producidos por la misma empresa de televisión y que por esta razón pueden ser reutilizados habitualmente con mínimas restricciones.

- Producción ajena, procedentes de agencias, otras televisiones, freelances o adquiridas en otros archivos (filmotecas, bancos de imágenes, productoras, etc.), que generalmente tienen algún tipo de restricción o salvedad a la hora de ser reutilizados.

En España, la Ley orgánica 10/1988, de las televisiones privadas, de 3 de mayo, en su artículo 14.6, obligaba ya a las empresas audiovisuales a guardar durante seis meses una copia de las emisiones, tal y como salen en antena, en prevención de cualquier reclamación (copia legal o judicial)². La Ley $7 / 2010$, de 31 de marzo, General de la comunicación audiovisual, capítulo IV, título VI, artículo 61.1, vigente en la actualidad fija que "A los efectos de la correcta dilucidación 
de la responsabilidad administrativa, los prestadores del servicio deberán archivar durante un plazo de seis meses a contar desde la fecha de su primera emisión, todos los programas emitidos, incluidas las comunicaciones comerciales, y registrar los datos relativos a tales programas" ${ }^{3}$. Como explicaremos más adelante, en el caso de las televisiones son frecuentes las demandas ocasionadas precisamente por una errónea reutilización de las imágenes de archivo.

No todas las imágenes que se gestionan y conservan en los archivos de las televisiones son reutilizables. Por diversos motivos, hay documentos audiovisuales, tanto de producción propia como de producción ajena, que no pueden y/o no deben reutilizarse, al menos en ciertos modos y ocasiones, para la producción y emisión diarias de las cadenas de televisión. Los medios de comunicación deben ser rigurosos no sólo con las imágenes que se captan y emiten por primera vez sino también con las imágenes de archivo que se reutilizan a diario, especialmente en los programas informativos, para no contravenir ningún derecho fundamental de los individuos que genere perjuicios que en ocasiones son muy difíciles y costosos de reparar.

\section{Problemas derivados de la reutilización indebida de imágenes de archivo}

La reutilización de imágenes de archivo de televisión debe ser conforme a derecho. En nuestra opinión, los problemas que suelen derivarse de la reutilización indebida de imágenes de archivo tienen más que ver con el incumplimiento de algunos aspectos del "derecho de comunicación pública" que con "los derechos de autor" (que suelen observarse y gestionarse correctamente) o con los derechos contractuales (pactados entre productores y difusores); es decir, la mayor parte de los problemas originados por la reutilización de algunas imágenes tienen que ver con la vulneración del derecho a la imagen, el derecho al honor o la intromisión en la vida privada de las personas, más que con otro tipo de cuestiones.

No todas las imágenes que se gestionan y conservan en los archivos de las televisiones son reutilizables

Intentaremos hacer una clasificación sencilla y sinóptica del tipo de derechos que deben salvaguardarse en relación con la emisión y reutilización de imágenes en televisión, para facilitar en lo posible la comprensión de un problema que es en realidad bastante complejo. Habría que atender a tres clases de derechos, según su naturaleza:

\subsection{Derechos contractuales}

El autor o titular de los derechos de las obras audiovisuales (productor y/o distribuidor) tiene el monopolio de su explotación y por tanto ostenta los derechos sobre la reproducción, distribución, comunicación pública, transformación y colección. Puede ceder o autorizar esos derechos a otros sujetos, por ejemplo a las televisiones, mediante contrato. Cuando las empresas de televisión firman los contratos con las agencias informativas o las productoras con las que trabajan, fijan las condiciones de archivado y reutilización de estas imágenes e informaciones; es evidente que la empresa o sujeto que detenta los derechos de unas imágenes posee y arbitra los mecanismos adecuados para controlar y proteger la utilización y distribución de éstas y la empresa que las adquiere debe respetarlos.

\section{Es necesario un control en la reutiliza- ción en programas informativos de imá- genes procedentes de webs}

Las posibilidades de reutilización de las imágenes son muchas, pudiendo ir desde el permiso de archivado y reutilización indefinido o mientras dure la relación contractual, hasta la imposibilidad de reutilizar o archivar pasadas 24 horas. Desde que en las televisiones se trabaja en entorno digital total, incluyendo el archivo digital de la cadena, muchas agencias y productoras han optado por impedir el archivado definitivo de sus imágenes y por tanto su reutilización a no ser que se renueve un acuerdo comercial para tal fin. Hay también limitaciones que vienen determinados por las llamadas "ventanas" según las cuales hay unos períodos de carencia (embargo) y/o prioritarios para unos ámbitos geográficos (p. ej.: emitir sólo para España, no emitir en territorio de la Unión Europea de Radiodifusión (UER), no emitir en Canal internacional, etc.) y para unos soportes de difusión sobre otros (p. ej.: no usar en webs, no utilizar para dispositivos móviles, etc.). Es frecuente también que existan imágenes de archivo con la prohibición expresa de ser reutilizadas para programas de contenidos determinados (p. ej.: prensa del corazón) o que se limite el tiempo y/o la duración de las imágenes que pueden reutilizarse (p. ej.: no emitir más de dos minutos, no reutilizar pasadas 48 horas).

La reutilización de imágenes de deportes en los programas de televisión suele ser especialmente complicada por el sistema de adquisición y explotación de los derechos audiovisuales de las competiciones y la multiplicidad de derechos e intereses comerciales y de imagen que confluyen.

\subsection{Derechos de propiedad intelectual}

La protección jurídica del autor de las obras audiovisuales originales debe quedar asegurada en los términos de la legislación vigente, tanto en lo que a derechos patrimoniales como a derechos morales se refiere. Ante la dificultad de gestionar individualmente estos derechos por parte de autores y usuarios en el ámbito de los medios de comunicación, con las difusiones y redifusiones múltiples de obras audiovisuales, existen entidades de gestión colectiva de estos derechos [Sociedad General de Autores de España (SGAE), Derechos de autor de Medios Audiovisuales (DAMA), etc.] con quienes las televisiones acuerdan en principio las pautas de actuación al respecto.

\subsection{Derechos fundamentales}

Las personas físicas y/o jurídicas que aparecen en las imágenes deben tener garantizados los derechos de imagen, el 


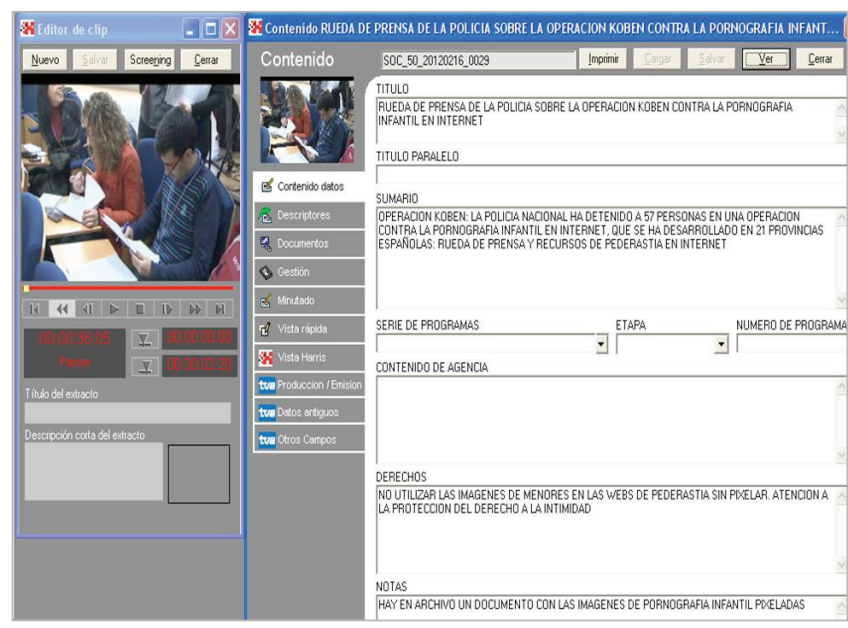

Figura 1. Metadatos de imágenes de archivo con la información correspondiente a sus condiciones de reutilización (base de datos Invenio. Documentación PP // TVE).

derecho al honor o a la intimidad, entre otros (AzurmendiAdarraga, 1997). El derecho a la propia imagen impide entre otras cosas la difusión de la misma a no ser con el consentimiento propio. Salvaguardar estos derechos del individuo al difundir imágenes en televisión es cumplir con lo que marca la Constitución española, capítulo II, sección 1, artículo 18.1 que garantiza "el derecho al honor, a la intimidad personal y familiar y a la propia imagen"4. Este derecho no se extingue aunque la persona haya fallecido.

Los mismos principios se recogen en la Ley $7 / 2010$, de 31 de marzo, General de la comunicación audiovisual, título II, capítulo I, artículo 4.4: "La comunicación audiovisual debe respetar el honor, la intimidad y la propia imagen de las personas y garantizar los derechos de rectificación y réplica. Todo ello en los términos previstos por la normativa vigente ${ }^{\prime \prime}$. Sólo cuando existan razones objetivas en relación con el interés público de la información se podría obviar el consentimiento de la persona o personas implicadas para proceder a la difusión de su imagen en una cadena de televisión, especialmente cuando se trata de personas con cargos públicos o de "famosos" en el ejercicio de su actividad profesional.

La compra de imágenes de archivo no supone la plena libertad para realizar cualquier tipo de modificaciones en las mismas

En este apartado surge la mayoría de los problemas ocasionados por la reutilización indebida de imágenes, consecuencia generalmente de una mala práctica de los profesionales, a pesar de que los libros de estilo de los medios de comunicación suelen hacer referencia expresa a este tipo de cuestiones. La Ley orgánica 1/1982, de 5 de mayo, sobre Protección civil del derecho al honor, a la intimidad personal y familiar, y a la propia imagen reconoce la posibilidad de pedir una indemnización por "daño moral" al respecto 6 . Lo ético y lo legal deben confluir de manera que no se de pie a reclamaciones por la vulneración de estos derechos fundamentales.

Por estas razones, al reutilizar las imágenes de archivo para elaborar una nueva información, se debería evitar en líneas generales:

- Reutilizar planos de personas, instituciones, organizaciones o empresas reconocibles o identificables para ilustrar informaciones de carácter negativo.

- Reutilizar imágenes de enfermos, heridos o accidentes para ilustrar esos temas pero en otro contexto o en el caso de informaciones sobre distintos accidentes.

- La reutilización reiterativa de imágenes de archivo determinadas en informaciones sobre cuestiones como la obesidad, el tabaquismo, el alcoholismo o las adicciones, para evitar las reclamaciones de personas o colectivos sociales que aparecen en ellas convertidas en "rostro" de esos problemas.

- Emplear imágenes de menores a los que se pueda reconocer en informaciones fuera del contexto para el que se grabaron, especialmente como recurso de imagen en informaciones sobre hechos delictivos o en las que se discutan su tutela o filiación.

- Reutilización de planos de personas en riesgo de exclusión social (mendigos, inmigrantes sin papeles, presos, prostitutas, etc.) en las que se les pueda identificar fácilmente.

- Los hechos delictivos "no son genéricos" por lo que no se deberían reutilizar imágenes de archivo de un caso concreto para ilustrar otro.

- La reutilización de imágenes de personas anónimas imputadas en casos judiciales sin sentencia, puesto que es necesario respetar la presunción de inocencia.

- Imágenes de los miembros de cuerpos y fuerzas de seguridad en el ejercicio de su actividad profesional que puedan ser identificados.

- Utilizar imágenes de celebraciones o prácticas religiosas como recurso en informaciones negativas relacionadas con alguna persona o colectivo practicante de esa confesión, de manera que no se contribuya a fijar estereotipos. - Debe respetarse la intimidad y el derecho a la confidencialidad de los individuos. En ocasiones, antes del rodaje se pacta con los protagonistas de la información la posibilidad de reutilizar o no las imágenes fuera de contexto o en programas distintos al de su primera emisión.

En las noticias y programas se deben identificar de forma clara y precisa las imágenes de archivo que se han utilizado, de manera que no se confunda al telespectador.

El Departamento de Documentación debe estar perfectamente informado sobre los derechos de reutilización de las imágenes. No se cuestiona si el control sobre los derechos de reutilización de la imágenes de archivo debe ser competencia suya o del Departamento de Producción, pero sí se constata el hecho de que en las televisiones esa información no siempre se comunica o no se notifica de manera suficientemente clara y puntual, para que los documentalistas puedan hacer constar en los documentos analizados los metadatos relativos a los límites o restricciones de uso si existieran, de manera que se garantice una información correcta al usuario que solicita reutilizar las imágenes de archivo. 


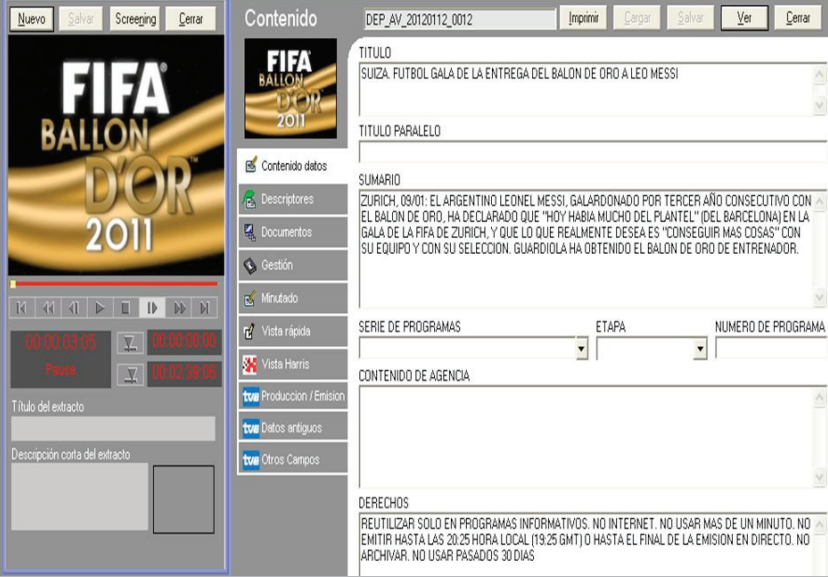

Figura 2. Ejemplo de metadatos de un clip de imágenes de deportes, tema cuyas condiciones de reutilización habitualmente son muy restrictivas (base de datos Invenio. Documentación PP /I TVE)

En las televisiones se debería trabajar en lo posible con sistemas informáticos que impiden automáticamente la edición con imágenes de archivo sujetas a restricciones, y que gestionan la reutilización de imágenes de archivo en el trabajo diario de la producción, de manera que se evitaran algunas situaciones como, por ejemplo, la utilización abusiva de determinadas imágenes o la reutilización de las que ya han originado reclamaciones. Pero en ocasiones cuestiones económicas y/o técnicas no lo permiten.

En cuanto a los derechos contractuales, los errores de reutilización de imágenes suelen subsanarse de la manera estipulada en cada caso en los contratos comerciales vigentes, pero, en el caso de las imágenes reutilizadas indebidamente en el resto de los supuestos descritos, puede acabarse dirimiendo la causa en los tribunales si alguna de las personas sujetas a derecho los considera vulnerados. En este contexto, padres o tutores de menores, empresas, organizaciones, instituciones o ciudadanos plantean sus quejas al respecto a los defensores del espectador de las cadenas de televisión o interponen demandas ante los juzgados pertinentes por la reutilización indebida de imágenes de archivo; en algunas ocasiones es suficiente con una rectificación por parte de la cadena de televisión y el firme compromiso de arbitrar los sistemas necesarios para que esas imágenes no se vuelvan a utilizar, pero en otras ocasiones, según la gravedad del caso, la sentencia conlleva el pago de indemnizaciones económicas de importante cuantía e incluso el expurgo físico de esas imágenes del archivo por orden judicial (por ejemplo imágenes de menores delincuentes internados en centros de acogida que puedan ser identificados). Estas reclamaciones son habituales e incluso existen gabinetes jurídicos especializados en este tipo de demandas.

En la reutilización de imágenes de archivo existe otra mala práctica habitual, más patente aún en las televisiones que trabajan en entorno digital, en las que los usuarios del archivo (redactores, realizadores, guionistas, etc.), equipados para su trabajo con nuevas herramientas, pueden recuperar documentos de archivo en modo "autoservicio" a través de las bases de datos, de manera que en muchos casos, suelen reutilizar las imágenes que ya conocen o las que encuen-

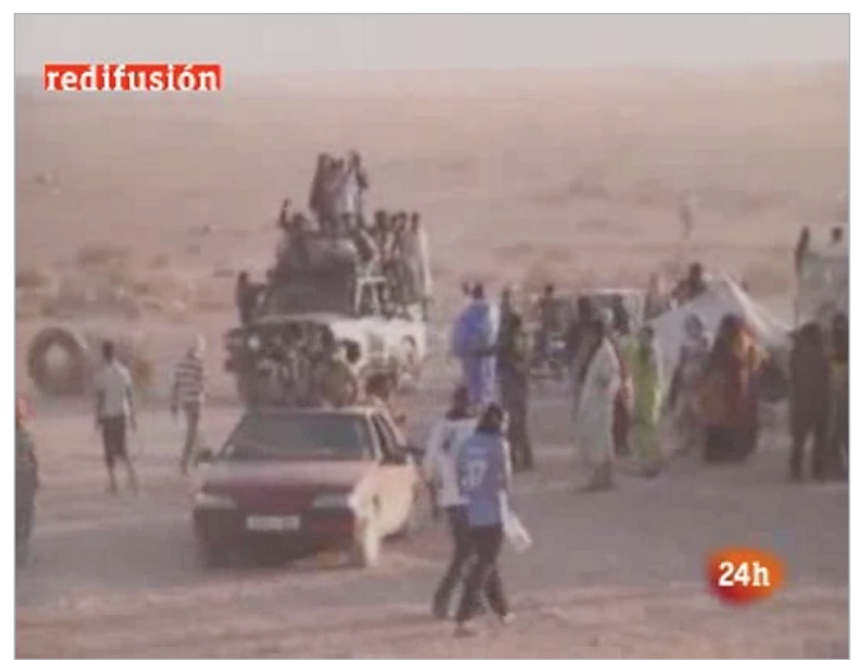

Figura 3. Imagen procedente de internet incluida en el reportaje "La intifada saharaui" (13/11/2010) de Informe semanal http://www.rtve.es

tran más fácilmente a través de estrategias de búsqueda sencillas. Los archivos audiovisuales de las televisiones se actualizan diariamente y por eso no es lógico que en ocasiones se incluyan en informaciones de actualidad imágenes repetidas de manera reiterada, incluso a veces anacrónicas. En líneas generales, son los profesionales del Departamento de Documentación quienes conocen suficientemente el fondo documental en su conjunto como para recuperar las imágenes más idóneas para reutilizar en cada caso, según las necesidades marcadas por el informador.

\section{Internet como fuente y archivo audiovisual}

Las imágenes procedentes de internet se han convertido en una fuente audiovisual más a la que acuden los periodistas para completar sus informaciones. De hecho, es ya habitual en las redacciones de los informativos la captura y digitalización de páginas de organizaciones, instituciones públicas o privadas, medios de comunicación, páginas personales, blogs, y redes sociales (como YouTube o Flicker) (AguilarGutiérrez; López-De-Solís, 2010).

En el caso de las redes sociales, los periodistas han encontrado un auténtico filón para recoger las primeras impresiones de personalidades (especialmente deportistas y políticos) que a través de su perfil de Facebook o Twitter expresan sus opiniones o dan a conocer una noticia. También acuden a estas redes sociales para informar sobre acontecimientos en lugares a los que los periodistas no pueden acceder por verse limitado su acceso a la información o como un primer acercamiento a una noticia.

Similar uso nos encontramos con la utilización de imágenes procedentes de YouTube o de webs donde se alojan videos concebidos para ser difundidos a través de la Red, a menudo con una clara vocación de influencia social (Díaz-Arias, 2008). En este caso la sección de Internacional es una de las que más acude a este tipo de material. Un ejemplo de este fenómeno lo encontramos incluso en Informe semanal, programa esencial para conocer la historia y el desarrollo de la información en TVE. Así, en el reportaje titulado "La intifada saharaui" (13/11/2010), ante la prohibición del gobierno marroquí de que los medios internacionales acudieran a $\mathrm{EI}$ 

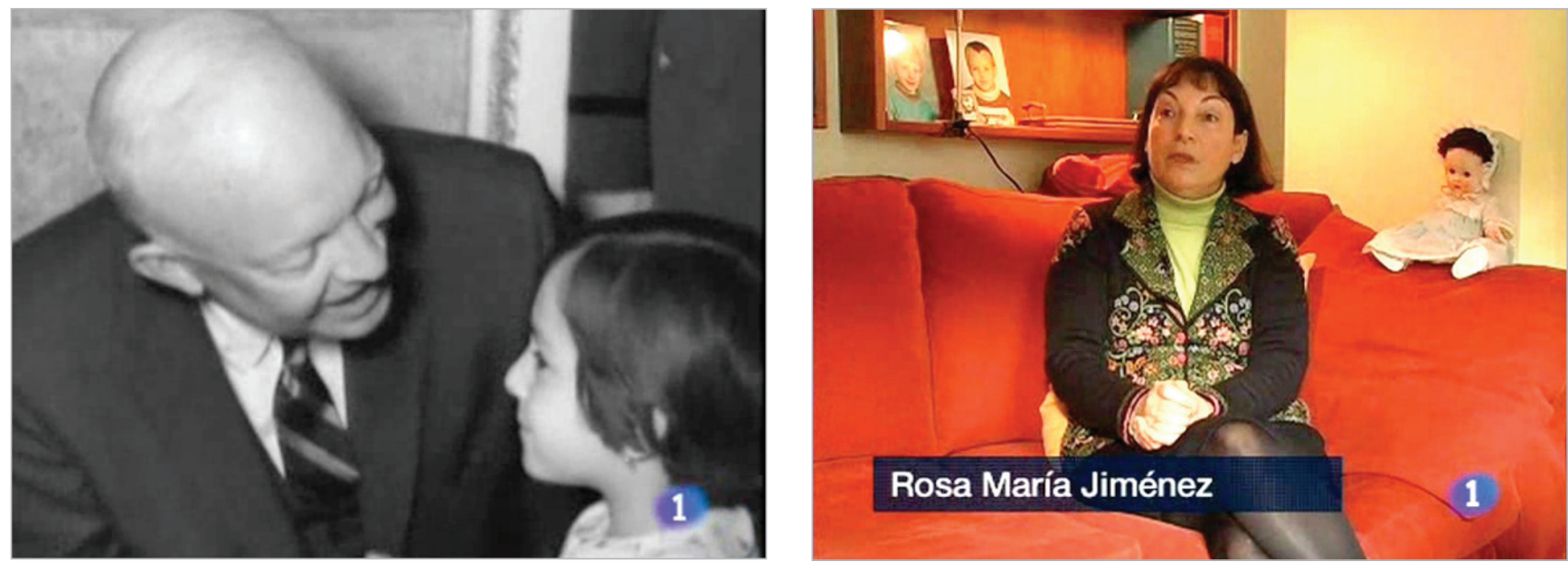

Figura 4. Fotogramas del ¿Te acuerdas? (TVE) sobre la visita de Eisenhower a España en 1959. A la izquierda encuentro de Eisenhower con la niña RosaMaría Jiménez. A la derecha, Rosa-María Jiménez en 2009 (fuente: RTVE) http://www.youtube.com/watch?v=pZWCIXturL8

Aaiún para informar de las protestas y enfrentamientos ocurridos en 2010, se optó por incluir videos colgados en YouTube por parte de activistas de la asociación Thawra, dedicada a denunciar la situación del pueblo saharaui.

Sin embargo no podemos sino mirar con cierta preocupación el hecho de que los periodistas acudan a YouTube como una fuente audiovisual más:

- YouTube es un mero intermediario de servicios de alojamiento de contenidos. En 2010 el Juzgado Mercantil número 7 de Madrid desestimó la demanda presentada por Telecinco contra YouTube por incluir videos que vulneraban los derechos de propiedad intelectual. Según esta sentencia, este portal de videos no está obligado a controlar el material que suben los internautas. Por ello, estas imágenes deben ser tratadas con suma precaución por parte de los periodistas y comprobar su veracidad. No olvidemos que cualquiera puede subir un video, falsear su identidad e incluso el video.

- YouTube no es propietaria de los derechos del material que aloja, lo que supone un riesgo para la empresa informativa que usa los videos allí encontrados, pues puede verse envuelta en un conflicto judicial.

- La calidad técnica de las imágenes procedentes de YouTube habitualmente es inferior a la de las fuentes tradicionales audiovisuales, por lo que su uso debe limitarse a su valor informativo (verificando previamente su autenticidad). Sin embargo, percibimos con cierta preocupación que en algunos casos los periodistas acuden a YouTube como si fuera un archivo audiovisual más, buscando en él noticias o imágenes que son utilizadas como recursos en sus piezas, sin plantearse previamente si dichas imágenes o similares pueden encontrarse en el archivo de la cadena.

\section{Compra de imágenes de archivo para producciones audiovisuales}

En la actualidad, es habitual el uso de imágenes de archivo en documentales televisivos, series o programas. También en determinadas ocasiones los programas informativos, especialmente en la elaboración de reportajes, adquieren imágenes procedentes de archivos nacionales o internacio- nales. En todos estos casos se negocia la compra de esas imágenes de forma independiente y particular, a menudo por un "documentalista de programas" o film researcher. Para ello, los archivos ofrecen diversas licencias, siendo las más habituales:

- Royalty free: Tarifa fija establecida para imágenes independientemente de su uso. Es habitual en la venta de imágenes genéricas (vistas de ciudades, de playas, de animales...)

- Rights managed (derechos gestionados): Tarifa determinada por el ámbito de distribución o emisión, el tiempo de cesión de los derechos, el cauce de distribución, la procedencia del material, el tipo de proyecto y el formato de entrega.

Sin embargo, la compra de material audiovisual no supone la plena libertad para realizar todo tipo de modificaciones de las imágenes. Es habitual que los archivos establezcan cláusulas en los contratos referentes al respeto a la integridad del material original, así como el derecho a ser informados previamente ante cualquier alteración (coloreado, alteración en el orden de los planos, modificación en la música e inclusión de una persona en las imágenes o efecto Forrest Gump). También pueden exigir ser informados con detalle del uso de esas imágenes para evitar una utilización ofensiva o poco respetuosa. En este sentido, algunos archivos, especialmente los públicos, incluyen en los contratos la obligatoriedad de enviar una copia de la producción audiovisual para verificar el uso correcto de las imágenes vendidas.

Otra cuestión a tener en cuenta son los denominados derechos a terceros, lo que supone a menudo por parte del comprador la gestión de los derechos de una obra musical o artística incluida en el material de archivo o incluso en algunos casos, los derechos de imagen. Por ejemplo, en la pieza de la ya desaparecida sección de los informativos de TVE ¿Te acuerdas? sobre la visita de Eisenhower a España, emitida el 20 de diciembre de 2009, se adquirieron imágenes procedentes de la CBS sobre el encuentro del presidente de los EUA con una niña española. Previamente a su venta, el archivo norteamericano solicitó la autorización de la ya mujer protagonista de esta historia. 


\section{Conclusiones}

No todas las imágenes que se gestionan y conservan en los archivos de las televisiones son susceptibles de reutilización. Por diversos motivos, hay documentos audiovisuales, tanto de producción propia como de producción ajena, que no pueden y/o no deben reutilizarse, al menos en ciertos modos y ocasiones, para la producción y emisión diarias de las cadenas de televisión. La reutilización de imágenes de archivo debe ser conforme a derecho. Las condiciones fijadas en los contratos, la propiedad intelectual y los derechos fundamentales y de imagen de las personas físicas y/o jurídicas deben salvaguardarse.

La información sobre los derechos de reutilización de las imágenes que pasan a formar parte del fondo documental de una televisión diariamente debería ser fluida y concisa en el entorno empresarial, para que el Departamento de Documentación pueda incluirla como metadato importante en el campo correspondiente de las fichas de análisis y no se generen dudas al respecto de posibles restricciones en la reutilización de las imágenes de archivo.

Internet se ha convertido en una fuente audiovisual más en televisión. Sin embargo, es necesario un mayor control en la reutilización de las imágenes procedentes de diferentes webs, valorando el valor informativo de las mismas, su procedencia y calidad.

\section{Notas}

1. FIAT. Directrices para el uso correcto del material de archivo en film o video. Londres, 1998, 2 pp.
2. Ley orgánica 10/1988 de 03/05/1988, de las televisiones privadas. BOE n. 134, 06/06/2006, pp. 21207-21218.

3. Ley $7 / 2010$ de $31 / 03 / 2010$, general de la comunicación audiovisual. BOE n. 79, 01/04/2010, pp. 30157-30209.

4. Constitución española. BOE n. 311, 29/12/1978, pp. 29313-29424.

5. Ley $7 / 2010$ de $31 / 03 / 2010$, general de la comunicación audiovisual. BOE n. 79, 01/04/2010, p. 30167.

6. Ley orgánica $1 / 1982$ de $05 / 05 / 1982$, sobre el derecho al honor, a la intimidad personal y familiar y a la propia imagen. $B O E$ n. 115 , de $14 / 05 / 1982$, pp. $12546-12548$

\section{Bibliografía}

Aguilar-Gutiérrez, Manuel; López-De-Solís, Iris (2010). “EI uso de imágenes de internet en los informativos de TVE". En: Jornades catalanes d'informació i documentació.

http://eprints.rclis.org/14731/1/AGUILAR_uso_imagenes_ internet_tve.pdf

Agirreazaldegi-Berriozabal, Teresa (1997). El uso de la documentación audiovisual en los programas informativos diarios de televisión. Bilbao: Universidad del País Vasco / Euskal Herriko Unibertsitatea. ISBN 8475858813

Azurmendi-Adarraga, Ana (1997). El derecho a la propia imagen: su identidad y aproximación al derecho a la información. Madrid: Civitas. ISBN 97884470009701

Díaz-Arias, Rafael (2008). "Análisis y tratamiento de las fuentes audiovisuales". Documentación de las ciencias de la información, v. 31, pp. 131-181.

\section{Próximos temas centrales}

Marzo 2014

Mayo 2014

Julio 2014

Septiembre 2014

Noviembre 2014

Enero 2015

Marzo 2015
Políticas de información

Visualización de información

Altmétricas

Humanidades digitales

Big data y analítica web

Informática vestible (wearable computing)

Marketing de productos de información

Los interesados por favor consulten detenidamente las Normas para autores:

http://www.elprofesionaldelainformacion.com/autores.html

y luego envíen sus artículos a través del gestor de manuscritos OJS de la plataforma del Recyt: http://recyt.fecyt.es/index.php/EPI/index 